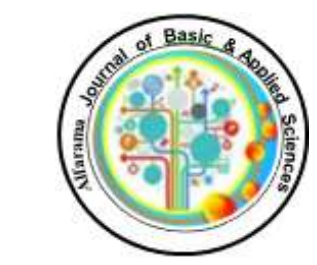

ISSN 2682-275X
Alfarama Journal of Basic \& Applied Sciences

Faculty of Science Port Said University https://ajbas.journals.ekb.eg

ajbas@sci.psu.edu.eg

http://sci.psu.edu.eg/en/

July 2021, Volume 2, Issue 2

DOI: $\underline{10.21608 / A J B A S .2021 .67687 .1048}$

Submitted: 25 /05 / 2021

Accepted: 14 / $06 / 2021$

Pages: 285-296

\title{
In Vitro Efficacy Of Biologically Active Compounds Derived From Navicula Arenaria Against Soil Borne Phytopathogenic Macrophomina Phaseolina And Fusarium Oxysporum
}

\author{
Asmaa lotfi alallaf ${ }^{1 *}$, metwally kottb ${ }^{2}$, ahmed k. El-sayed ${ }^{3}$ and hesham shafik ${ }^{1,4}$ \\ ${ }^{1}$ Botany department, Faculty of Science, Port Said University. \\ ${ }^{2}$ Botany and Microbiology department, Faculty of Science, Suez Canal University. \\ ${ }^{3}$ Botany and Microbiology Department, Faculty of Science, Damietta University. \\ ${ }^{4}$ Department of Hydraulic and water Resources Engineering, Budapest University of Technology and \\ Economics. \\ *Correspondence: asmaa.alallaf@sci.psu.edu.eg
}

\begin{abstract}
Navicula arenaria Donkin 1861 is a marine microalga belongs to class of bacillariophycea. Recently, microalgae and their products are used as biological control of diseases caused by phytopathogenic fungi. This is considered environmentally ecofriendly method to overcome the plant damage caused by soil borne pathogenic fungi and thereby economic loss. Therefore, this study aimed to investigate in vitro the antifungal activity of $N$. arenaria isolate PS 31 extracellular and intracellular metabolites against two taxa of soil borne phytopathogenic fungi; Macrophomina phaseolina and Fusarium oxysporum.

$N$. arenaria PS 31 hexane extract was the most effective extract on growth inhibition of both phytopathogenic fungi. There is no significant difference between miconazole and $N$. arenaria hexane extract of $5.6 \mathrm{mg} / \mathrm{ml}$ on growth inhibition of $F$. oxysporum. The inhibitory effect of hexane extract at 5.6, 4.2 and $2.8 \mathrm{mg} / \mathrm{ml}$ and ethyl acetate extract at $35 \%(\mathrm{v} / \mathrm{v})$ was higher than controls. Ethyl acetate extract was effective on growth inhibition of $M$. phaseolina (29.67\%). GC-MS analysis of $N$. arenaria hexane fraction revealed the presence of potent antifungal compounds such as Phenol, 2,2'-methylenebis[6-(1,1-dimethylethyl)-4methyl-, di-n-octyl phthalate, cholestane-3,5-diol, 5-acetate,(3.beta.,5.alpha.), Cholestan-3ol,(3.beta.,5.beta.)- and beta.-Sitosterol. These results suggest that $N$. arenaria hexane extract can be used in biological control of plant diseases caused by M. phaseolina and $F$. oxysporum.
\end{abstract}

Keywords:

Antifungal activity; Diatoms; Fusarium oxysporum; Macrophomina phaseolina; Navicula arenaria . 


\section{INTRODUCTION}

Diatoms are unicellular microalgae with silica shields and belong to class of bacillariophycae. Diatoms are ubiquitous photosynthetic organisms that are found in freshwater, seawater, brackish water and terrestrial habitat [1]. Microalgae are naturally rich with several metabolites that have several biological activities such as antifungal, antibacterial, antiviral, anti-oxidative, antitumor and anti-inflammatory [2]. In recent years, algae are used in many applications such as biofuels and bioplastics production, nutritional supplements, cosmetics, bioremediation, animal feeds, agriculture branches as fertilizers, biostimulants or in biocontrol and pharmaceutical industry [2].

The plant damage caused by soil borne pathogenic fungi has led to the focusing of considerable effort for fighting plant pathogens using natural products extracts as safe alternatives to synthetic fungicide [3]. Conventional strategies that involves the utilization of chemical fungicides are used in the control of soil borne phytopathogenic fungi. However, the application of synthetic fungicides can cause harmful problems to the environment and other organisms [4]. As a consequence, there is an increased attention toward the utilization of algae as a biocontrol agent for plant disease management to reduce the use of fungicides and this considered ecofriendly method to environment for protecting crops from soil borne pathogenic fungi $[5,6]$.

Okunowo [7] determine the antifungal activity of Navicula sp. methanol extract against Candida albicans. Qin et al. [8] evaluate the antimicrobial activity of marine diatom Thalassiosira rotula against three strains of Gram positive bacteria and six strains of Gram negative bacteria and Candida albicans. Sherief $e t$ al. [9] study the antimicrobial efficiency of marine diatoms (DE) and silver diatom nanoparticle (Ag-DE/NPs) against Bacillus cereus, Staphylococcus aureus, Escherichia coli, Candida albicans and Aspergillus niger. The results revealed that the antimicrobial activity of silver diatom nanoparticle was higher than the antimicrobial activity of marine diatoms.

The aim of this research is to evaluate the antifungal activity of $N$. arenaria metabolites against Fusarium oxysporum and Macrophomina phaseolina that are considered two sorts of soil borne pathogenic fungi.

\section{MATERIALS AND METHODS}

\subsection{Navicula arenaria isolation and identification}

Navicula arenaria was isolated and purified from sea water samples collected from Mediterranean Sea at Port Said city. F/2 medium has been used for $N$. arenaria isolation and purification [10]. The morphological identification of $N$. arenaria was accessed by light microscopy and imaged using optika 4083.B5 digital camera. The morphological identification was assessed according to Donkin, (1858) [11].

The molecular identification of $N$. arenaria was based on ITS-5.8s rRNA gene sequence analysis. Navicula arenaria chromosomal DNA was extracted by phenol/chloroform technique and precipitated by isopropanol followed by washing with ethanol [12]. The quality of the purified genomic was examined by running on agarose gel electrophoresis (1\%) in TAE buffer $\mathrm{pH} 8.0(0.04 \mathrm{M}$ Tris-acetate and $0.001 \mathrm{M}$ EDTA) and visualized by UV trans-illuminator after staining with ethidium bromide.

The ITS1 and ITS2 regions including 5.8S rRNA gene was amplified and sequenced using the universal eukaryotic primers ITS4 (5'-TCCTCCGCTTATTGATATGC- $3^{\prime}$ ) and ITS5 (5'-GGAAGTAAAAGTCGTAACAAGG-3') [13]. The amplified PCR products were 
sequenced by an automated sequencer (Macrogen, South Korea) using the same previous primers. Basic local alignment search tool nucleotide (BLASTn) was performed for search alignment of the resulting ITS region of DNA sequence to match the best similarities with other related sequences on database [14]. The best DNA sequence similarities with the resulting regions were obtained from national center for biotechnology information (NCBI) GenBank and aligned using CLUSTAL Omega. Unaligned terminal regions were excluded manually and some sequences of the same species and unidentified organisms were discarded. Finally, phylogenetic tree analysis was viewed and analyzed using MEGA version 4 [15].

\subsection{Antifungal activity of $N$. arenaria metabolites}

$N$. arenaria PS 31 propagation was performed in 2L glass bottle media filled with 1800 $\mathrm{mL}$ media at $25^{\circ} \mathrm{C}$ under 8:16 LD cycle with $36 \mu \mathrm{mol} \mathrm{m} \mathrm{m}^{-2} \mathrm{~s}^{-1}$ with cool white fluorescent lamps and continuous aeration by vacuum pump $(3.5 \mathrm{~L} / \mathrm{min})$. Biomass of $N$. arenaria and cultivation medium were harvested after 35 days by centrifugation at $10000 \mathrm{rpm}$ [16]. $N$. arenaria biomass was washed with distilled water to remove salts and then air dried.

Four organic extraction solvents according to polarity; hexane, chloroform, acetone and methanol were used in extraction process of $N$. arenaria intracellular metabolites by maceration with continuous shaken for 24 hours at $200 \mathrm{rpm}$. The percentage of each extract was measured as follow $[17,18]$ :

Extract $\%=($ Weight of extract $(\mathrm{g}) /$ Weight of algal sample $(\mathrm{g})) * 100$

Each crude extract was dissolved in dimethyl sulfoxide (DMSO) then sterilized using micro filters (Millipore, $0.22 \mu \mathrm{m}$ ) and stored in refrigerator for further use. The concentration of each extract was calculated [18,19] .

$N$. arenaria extracellular metabolites were extracted according to modified method from Bhore et al., (2010) [20]. F/2 culture medium was extracted by absolute ethyl acetate $(1: 3 \mathrm{v} / \mathrm{v})$. The mixture was shaken for 24 hours at $200 \mathrm{rpm}$. The mixture was imparted in a separating funnel until the separation of ethyl acetate from the aqueous layer. The extract was sterilized through micro filters (Millipore, $0.22 \mu \mathrm{m}$ ) and stored in refrigerator for antifungal assay.

Antifungal efficiency of $N$. arenaria extracellular and intracellular metabolites was carried in vitro against $M$. phaseolina and $F$. oxysporum by agar diffusion method on potato dextrose agar medium [18,21]. Negative control was DMSO in case of intracellular metabolites and ethyl acetate in case of extracellular metabolites Positive control was performed by using miconazole and nystatin at $0.03 \mathrm{mg} / \mathrm{mL}$.

Plates were incubated at $30^{\circ} \mathrm{C}$ and the results of fungus growth inhibition were recorded after 96 hours in case of $M$. phaseolina and till 120 hours in case of $F$. oxysporum. Percentage of mycelium growth inhibition (MGI \%) was measured using the following equation $[18,22]$ :

$$
\text { MGI } \%=[(\text { Control }- \text { Test }) / \text { Control }] \times 100
$$

(Control= fungus radial growth from the middle of fungal disc toward the negative control well, Test= fungus radial growth from the middle of fungal disc toward the extract well).

Determination of MIC was achieved by using three diluting concentrations of each extract $(75,50$ and 25\%) [18]. All experiments were performed in triplicate.

\subsection{Metabolic profile of Navicula arenaria PS 31}

$N$. arenaria hexane fraction exhibited the highest antifungal activity against $M$. phaseolina and F. oxysporum. Hexane extract was analyzed using GC-MS. 
Mass spectra were recorded using Shimadzu GCMS-QP2010 (Koyoto, Japan) equipped with Rtx-5MS fused bonded column (30 m x $0.25 \mathrm{~mm}$ i.d. x $0.25 \mu \mathrm{m}$ film thickness) (Restek, USA) equipped with a split-splitless injector. This analysis was carried out in Faculty of Pharmacy, Ain Shams University. The initial column temperature was kept at $50^{\circ} \mathrm{C}$ for 3 min (isothermal) and programmed to $200^{\circ} \mathrm{C}$ at a rate of $15^{\circ} \mathrm{C} / \mathrm{min}$, and kept constant at $200^{\circ} \mathrm{C}$ for $5 \mathrm{~min}$ (isothermal). Temperature was programmed to $240^{\circ} \mathrm{C}$ at a rate of $3^{\circ} \mathrm{C} / \mathrm{min}$, and kept constant at $240^{\circ} \mathrm{C}$ for $10 \mathrm{~min}$ (isothermal). Finally, the temperature was programmed to $300^{\circ} \mathrm{C}$ at a rate of $4^{\circ} \mathrm{C} / \mathrm{min}$, and kept constant at $300^{\circ} \mathrm{C}$ for $10 \mathrm{~min}$ (isothermal). Injector temperature was $280^{\circ} \mathrm{C}$. Helium carrier gas flow rate was $1.41 \mathrm{ml} / \mathrm{min}$. All the mass spectra were recorded applying the following condition: (equipment current) filament emission current, $60 \mathrm{~mA}$; ionization voltage, $70 \mathrm{eV}$; ion source, $220^{\circ} \mathrm{C}$. Diluted samples $(1 \% \mathrm{v} / \mathrm{v})$ were injected with split mode (split ratio1:5).

\subsection{Statistical analysis}

The results were expressed as mean of three replicates \pm standard error. IBM SPSS software version 25 was used for results statistical analysis. Data was subjected to analysis of variance using one-way ANOVA at $\mathrm{P}<0.05$ in order to assess the significance among treatments and means were separated using the least significant difference (LSD) [23].

\section{RESULTS AND DISCUSSION}

\subsection{Identification of the $N$. arenaria isolate}

$N$. arenaria is mobile, oblong, narrow and acute cell. It has slightly convergent opposite central nodule. Cells are $22.83 \pm 0.186 \mu \mathrm{m}$ long and $4.14 \pm 0.586 \mu \mathrm{m}$ wide (Fig. 1).

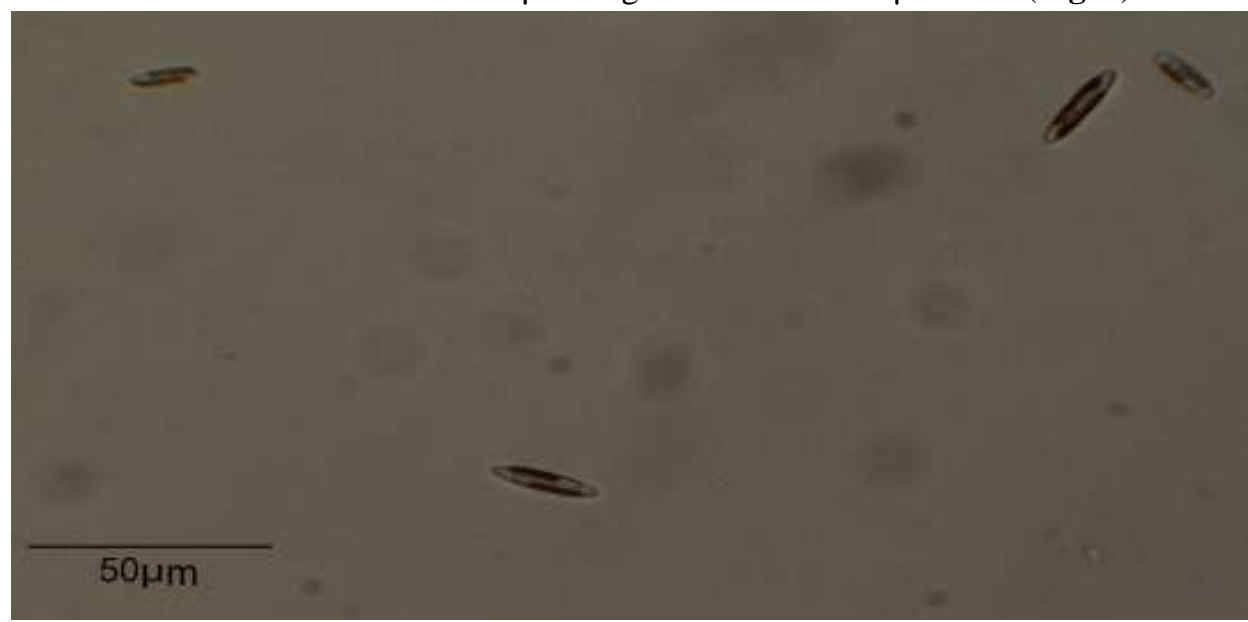

Fig. 1. Microscopic image of Navicula arenaria PS 31.

ITS-5.8s rRNA gene sequence alignment (NCBI-Blastn) of Navicula arenaria PS 31 isolate with other related Navicula genera exhibited the highest identity with Navicula arenaria isolate CCY 0228 (reached $82.10 \%$ similarity with query cover $95 \%$ and bootstrap value 100). Less query cover sequences with Navicula gregaria isolate K7 and K8 (39\% and $38 \%$ respectively) revealed $89 \%$ similarity but clustered away from Navicula arenaria PS 31 . The other Navicula species were grouped in a separate cluster away from the studied isolate as represented in the phylogenetic tree (Fig. 2).

The ITS-5.8S rRNA gene sequence confirmed the identification of Navicula isolate PS 31 as it clustered with Navicula arenaria isolate CCY 0228 in the same clade with similarity reached $82.10 \%$. Also, its morphological characteristics match with the other Navicula 
arenaria. On the other hand, cells of $N$. gregaria are broadly lanceolate and apiculate while cells of $N$. arenaria are narrowly lanceolate and acute and both habitat are marine [11]. Cells of Navicula arenaria PS 31 isolate are $22.83 \pm 0.186 \mu \mathrm{m}$ long and $4.14 \pm 0.586 \mu \mathrm{m}$ wide., while $N$. gregaria cell was 13 to $42 \mu \mathrm{m}$ long and 5 to $10 \mu \mathrm{m}$ wide [24].

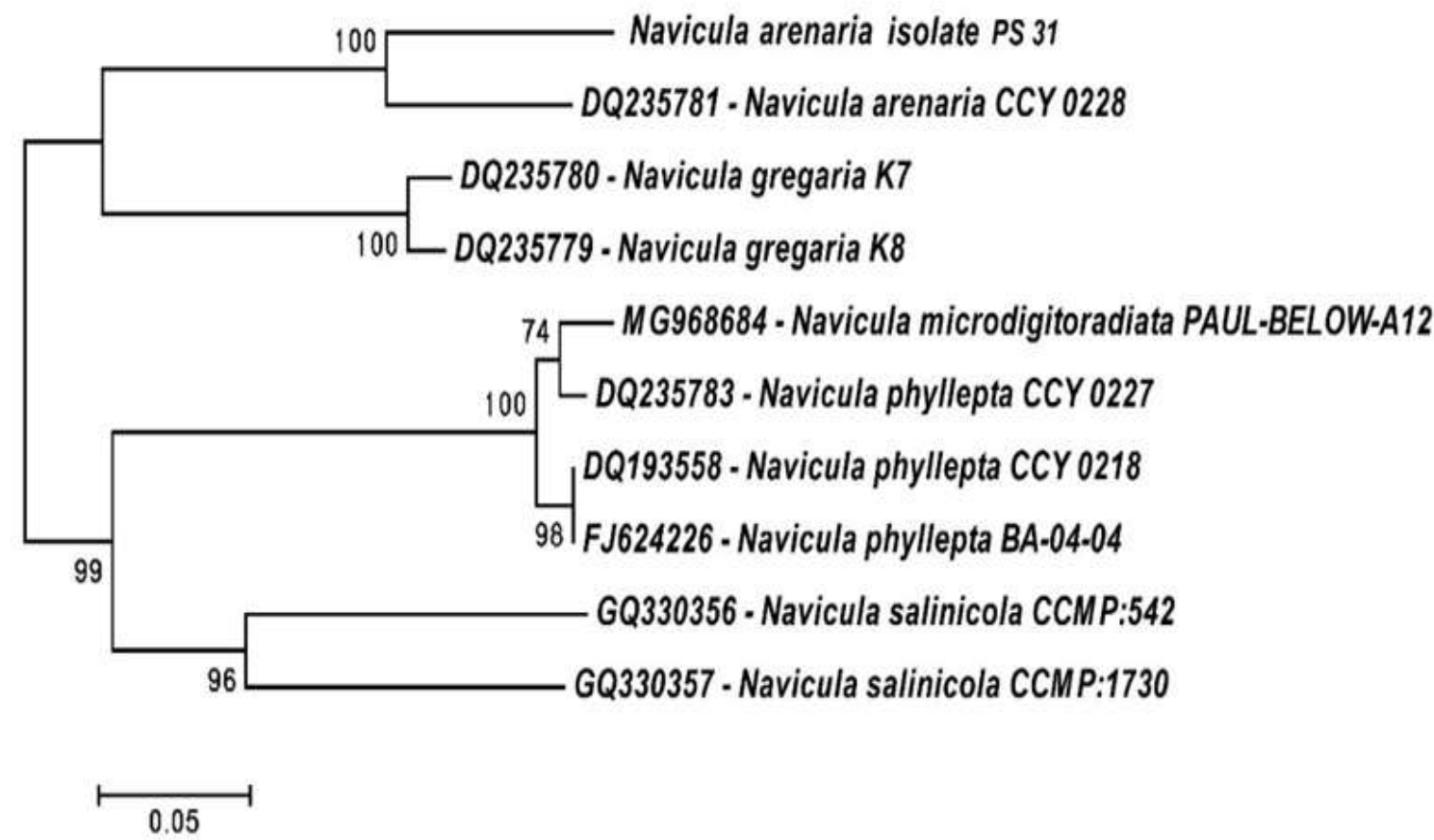

Fig. 2. Phylogenetic tree analysis based on ITS-5.8s rRNA gene sequence alignment of Navicula arenaria isolate PS 31 with some other related Navicula species. The values next to branches are confidence levels estimated by 1000 bootstrap replicates.

\subsection{Antifungal activity of $N$. arenaria extracts (In- vitro assay)}

Organic extraction solvents have an obvious effect on extraction yield. The highest concentration of $N$. arenaria extraction yield was obtained by acetone followed by methanol. The lowest extract concentration was obtained by hexane (Fig. 3). In consistent with our observations Lotfi et al. [18] who reported that the highest percentage of extraction yield in Ulva fasciata, Ulva lactuca and Cladophora sericea was obtained by methanol followed by acetone. Also, the results disagree with Abdel-Aal et al. [17] who found that the highest extraction yield from Spirogyra longata was obtained by methanol.

The highest MGI\% against $M$. phaseolina and $F$. oxysporum was observed by hexane extract. Both of soil-borne fungi are sensitive to Navicula arenaria hexane extract and resistant to methanol extract of this alga (Table. 1). This observation was contrasted to Okunowo [7] who found that Navicula sp. methanol extract inhibit the growth of all tested clinical isolates. $N$. arenaria hexane extract at $5.6 \mathrm{mg} / \mathrm{ml}$ showed $31.02 \mathrm{MGI} \%$ to $M$. phaseolina and 21.56 MGI\% against F. oysporum (Table. 2). M. phaseolina was resistant to chloroform, acetone and methanol extracts. In consistent with our observations Qin et al. [8] 
who found that Candida albicans was resistant to all tested extraction solvents of a marine diatom Thalassiosira rotula.

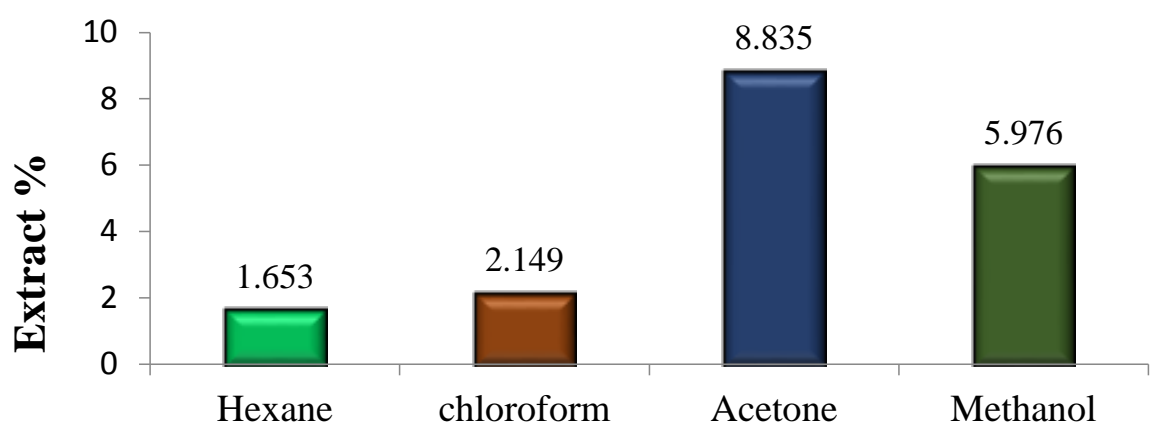

\section{Extraction solvents}

Fig. 3. Variation in crude extract $\%$ of $N$. arenaria with different organic solvents.

Antifungal activity of $N$. arenaria hexane extract of $5.6,4.2$ and $2.8 \mathrm{mg} / \mathrm{ml}$ concentrations against $M$. phaseolina was significantly higher than positive control (Table. 2). F. oxysporum was sensitive to hexane, chloroform and acetone extract at high concentrations. Methanol and ethyl acetate extract were not effective in growth inhibition of $F$. oxysporum. There is no significant difference in mycelium growth inhibition of $F$. oxysporum by miconazole and $N$. arenaria hexane extract. $N$. arenaria ethyl acetate extract was effective in growth inhibition of M. phaseolina (Fig. 5). The inhibitory effect of $N$. arenaria extracellular metabolites to $M$. phaseolina reached to $29.67 \%$. About $33.33 \%$ of ethyl acetate extracts from the cultivation medium inhibit the growth of tested fungi. Similarly, was reported by Mundt et al. [16] who found that $38 \%$ of the ethyl acetate extracts obtained from the cultivation medium inhibit the growth of tested fungi and bacteria. The whole difference between results of the present study and other researches result is due to the difference in tested microorganism, extraction solvent and method, type of alga and chemical composition of algae that differ according to species and environmental conditions [25]. 
Table 1. Determination of MIC for different concentrations of extraction solvents of $N$. arenaria against phytopathogenic fungi.

\begin{tabular}{|c|c|c|c|c|c|}
\hline \multirow{3}{*}{ Hexane } & Concentration $(\mathrm{mg} / \mathrm{ml})$ & 1.4 & 2.8 & 4.2 & 5.6 \\
\hline & F. oxysporum & - & - & - & + \\
\hline & M. phaseolina & + & + & + & + \\
\hline \multirow{3}{*}{ Chloroform } & Concentration $(\mathrm{mg} / \mathrm{ml})$ & 1.42 & 2.84 & 4.26 & 5.68 \\
\hline & F. oxysporum & - & - & - & + \\
\hline & M. phaseolina & - & - & - & - \\
\hline \multirow{3}{*}{ Acetone } & Concentration $(\mathrm{mg} / \mathrm{ml})$ & 0.61 & 1.23 & 1.84 & 2.46 \\
\hline & F. oxysporum & - & - & - & + \\
\hline & M. phaseolina & - & - & - & - \\
\hline \multirow{3}{*}{ Methanol } & Concentration $(\mathrm{mg} / \mathrm{ml})$ & 5.75 & $\mathbf{1 1 . 5}$ & $\mathbf{1 7 . 2 5}$ & 23 \\
\hline & F. oxysporum & - & - & - & - \\
\hline & M. phaseolina & - & - & - & - \\
\hline \multirow{3}{*}{$\begin{array}{c}\text { Ethyl } \\
\text { acetate }\end{array}$} & Concentration (v/v) & $5 \%$ & $15 \%$ & $25 \%$ & $35 \%$ \\
\hline & F. oxysporum & - & - & - & - \\
\hline & M. phaseolina & - & - & - & + \\
\hline
\end{tabular}

(+) means that the pathogen was sensitive to the extract and (-) means that the pathogen was resistant to the extract.

Table 2. MGI \% of phytopathogenic fungal candidates by different extraction solvents of $N$. arenaria.

\begin{tabular}{|c|c|c|c|}
\hline \multirow{2}{*}{ Treatments } & \multirow{2}{*}{ Extract Conc. } & \multicolumn{2}{|c|}{ MGI \% } \\
\hline & & F. oxysporum & M. phaseolina \\
\hline Miconazole & $0.03 \mathrm{mg} / \mathrm{ml}$ & $24 \pm 1.76^{a}$ & $10.76 \pm 2.98^{h}$ \\
\hline Nystatin & $0.03 \mathrm{mg} / \mathrm{ml}$ & $12.2 \pm 2.32^{b}$ & $14.86 \pm 0.63^{g}$ \\
\hline Hexane & $5.6 \mathrm{mg} / \mathrm{ml}$ & $21.56 \pm 0.46^{a}$ & $31.02 \pm 0.88^{\mathrm{e}}$ \\
\hline Hexane & $4.2 \mathrm{mg} / \mathrm{ml}$ & $0^{\mathrm{c}}$ & $27.27 \pm 0.30^{e}$ \\
\hline Hexane & $2.8 \mathrm{mg} / \mathrm{ml}$ & $0^{c}$ & $17.04 \pm 0.19^{g}$ \\
\hline Hexane & $1.4 \mathrm{mg} / \mathrm{ml}$ & $0^{\mathrm{c}}$ & $6.813 \pm 0.07^{i}$ \\
\hline Chloroform & $5.68 \mathrm{mg} / \mathrm{ml}$ & $18.07 \pm 0.22^{d}$ & $0^{\mathrm{f}}$ \\
\hline Acetone & $2.46 \mathrm{mg} / \mathrm{ml}$ & $13.54 \pm 1.01^{b}$ & $0^{\mathrm{f}}$ \\
\hline Methanol & $23 \mathrm{mg} / \mathrm{ml}$ & $0^{\mathrm{c}}$ & $0^{\mathrm{f}}$ \\
\hline Ethyl acetate & $35 \%$ & $0^{\mathrm{c}}$ & $29.67 \pm 0.32^{e}$ \\
\hline \multicolumn{2}{|c|}{ LSD at $p \leq 0.05$} & 3 & 2.92 \\
\hline
\end{tabular}

All values are mean $(n=3) \pm$ standard error.

Values with the same letters in the same column are not significantly different at $\mathrm{p} \leq 0.05$. 


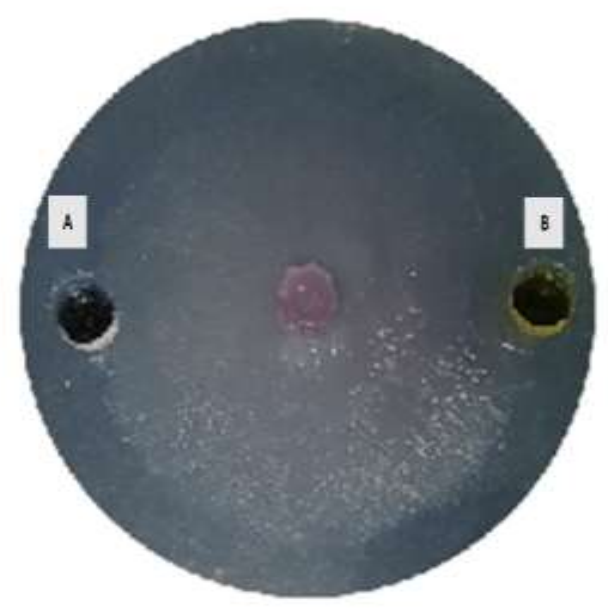

Fig. 4. Mycelial growth inhibition of $F$. oxysporum by $N$. arenaria hexane extract; A. represents DMSO only (negative control) and B. represents $N$. arenaria hexane extract dissolved in DMSO.

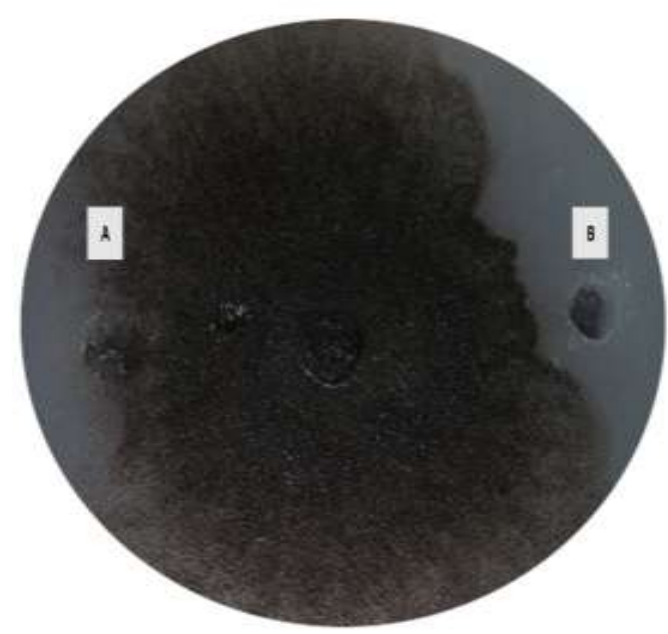

Fig. 5. Mycelial growth inhibition of $M$. phaseolina by extracellular metabolites of $N$. aenaria; A. represents ethyl acetate only (negative control) and B. represents extracellular metabolites of $N$. arenaria dissolved in ethyl acetate.

\subsection{Metabolic profile of Navicula arenaria PS 31}

The bioactivity of $N$. arenaria hexane extract was proved against two tested phytopathogenic fungi. Eight compounds were identified from $N$. arenaria hexane extract and belong to different chemical classes like steroids, diterpene alcohols, esters, fatty alcohols, phenols, phytosterols and phthalic acid derivatives (Table. 3, Fig. 6). Some of them were recorded as antifungal compounds like phenol, 2,2'-methylenebis [6-(1,1dimethylethyl)-4-methyl- [26], di-n-octyl phthalate [27], beta.-Sitostero [27], cholestan-3-ol, (3.beta.,5.beta.)- [28] and Cholestane-3,5-diol, 5-acetate, (3.beta.,5.alpha.)- [28]. The highest peak area in $N$. arenaria hexane fraction was identified as di-n-octyl phthalate (Fig. 7). 
Table 3. Identified compounds from $N$. arenaria hexane extract by GC/MS.

\begin{tabular}{|c|c|c|c|c|c|c|c|c|c|}
\hline $\begin{array}{l}\text { Peak } \\
\text { No. }\end{array}$ & $\mathbf{R}_{\mathbf{t}}$ & Metabolites & $\begin{array}{l}\text { Molecula } \\
\mathbf{r} \text { formula }\end{array}$ & $\begin{array}{c}\text { Molecular } \\
\text { weight }\end{array}$ & $\begin{array}{c}\text { Chemical } \\
\text { groups }\end{array}$ & $\begin{array}{c}\text { Base } \\
\text { peak } \\
\mathrm{m} / \mathrm{z}\end{array}$ & $\begin{array}{c}\text { Peak } \\
\text { area } \\
\%\end{array}$ & $\begin{array}{c}\text { Biological } \\
\text { activities }\end{array}$ & $\begin{array}{l}\text { Refer } \\
\text { ences }\end{array}$ \\
\hline 1 & 20.826 & 1-Eicosanol & $\mathrm{C}_{20} \mathrm{H}_{42} \mathrm{O}$ & 298 & Fatty alcohol & 43.05 & 3.02 & $\begin{array}{l}\text { Antimicrobi } \\
\text { al activity }\end{array}$ & [28] \\
\hline 2 & 21.571 & Phytol & $\mathrm{C}_{20} \mathrm{H}_{40} \mathrm{O}$ & 296 & $\begin{array}{c}\text { Diterpene } \\
\text { alcohol }\end{array}$ & 43.05 & 3.69 & $\begin{array}{l}\text { Antimicrobi } \\
\text { al activity }\end{array}$ & $\begin{array}{c}{[29,30} \\
]\end{array}$ \\
\hline 3 & 26.167 & $\begin{array}{c}\text { 2-Propenoic } \\
\text { acid, pentadecyl } \\
\text { ester }\end{array}$ & $\mathrm{C}_{18} \mathrm{H}_{34} \mathrm{O}_{2}$ & 282 & Acid & 55.05 & 14.35 & - & - \\
\hline 4 & 29.605 & $\begin{array}{c}\text { Phenol, 2,2'- } \\
\text { methylenebis[6- } \\
\text { (1,1- } \\
\text { dimethylethyl)- } \\
\text { 4-methyl- }\end{array}$ & $\mathrm{C}_{23} \mathrm{H}_{32} \mathrm{O}_{2}$ & 340 & Phenol & 177.10 & 3.85 & $\begin{array}{l}\text { Antifungal, } \\
\text { Antibacteri } \\
\text { al activity, } \\
\text { germicidal }\end{array}$ & [26] \\
\hline 5 & 32.901 & $\begin{array}{l}\text { Di-n-octyl } \\
\text { phthalate }\end{array}$ & $\mathrm{C}_{24} \mathrm{H}_{38} \mathrm{O} 4$ & 390 & $\begin{array}{c}\text { Phthalic acid } \\
\text { derivative }\end{array}$ & 149.05 & 38.32 & $\begin{array}{l}\text { Antifungal } \\
\text { activity }\end{array}$ & [27] \\
\hline 6 & 52.077 & $\begin{array}{l}\text { Cholestane-3,5- } \\
\text { diol, 5-acetate, } \\
\text { (3.beta.,5.alpha.) } \\
\text { - }\end{array}$ & $\mathrm{C}_{29} \mathrm{H}_{50} \mathrm{O}_{3}$ & 446 & Steroids & 43.05 & 4.98 & $\begin{array}{l}\text { Antifungal } \\
\text { activity }\end{array}$ & [28] \\
\hline 7 & 52.265 & $\begin{array}{l}\text { Cholestan-3-ol, } \\
\text { (3.beta.,5.beta.)- }\end{array}$ & $\mathrm{C}_{27} \mathrm{H}_{48} \mathrm{O}$ & 388 & Steroids & 43 & 8.20 & $\begin{array}{l}\text { Antifungal } \\
\text { activity }\end{array}$ & {$[28]$} \\
\hline 8 & 56.453 & beta.-Sitosterol & $\mathrm{C}_{29} \mathrm{H}_{50} \mathrm{O}$ & 414 & Phytosterols & 43.05 & 15.83 & $\begin{array}{l}\text { Antifungal } \\
\text { activity }\end{array}$ & [27] \\
\hline
\end{tabular}

(-) No reported biological activity 


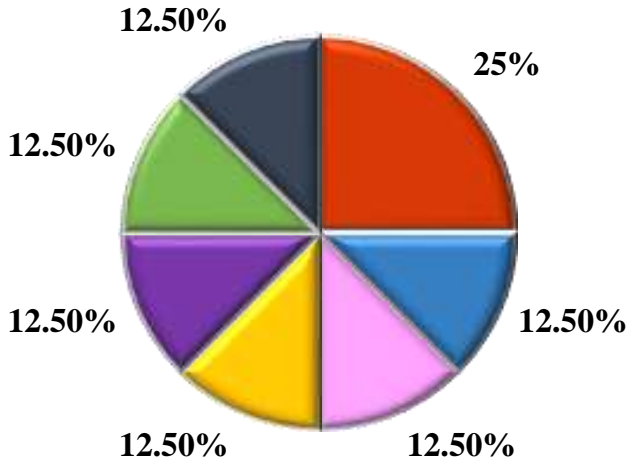

IuSteroids

SFatty alcohols

Inthalic acid derivatives

\section{Diterpene alcohols \\ uhenols}

4 Esters

Mhytosterols

Fig. 6. Percentage of metabolites chemical groups identified by GC/MS in N. arenaria hexane extract.

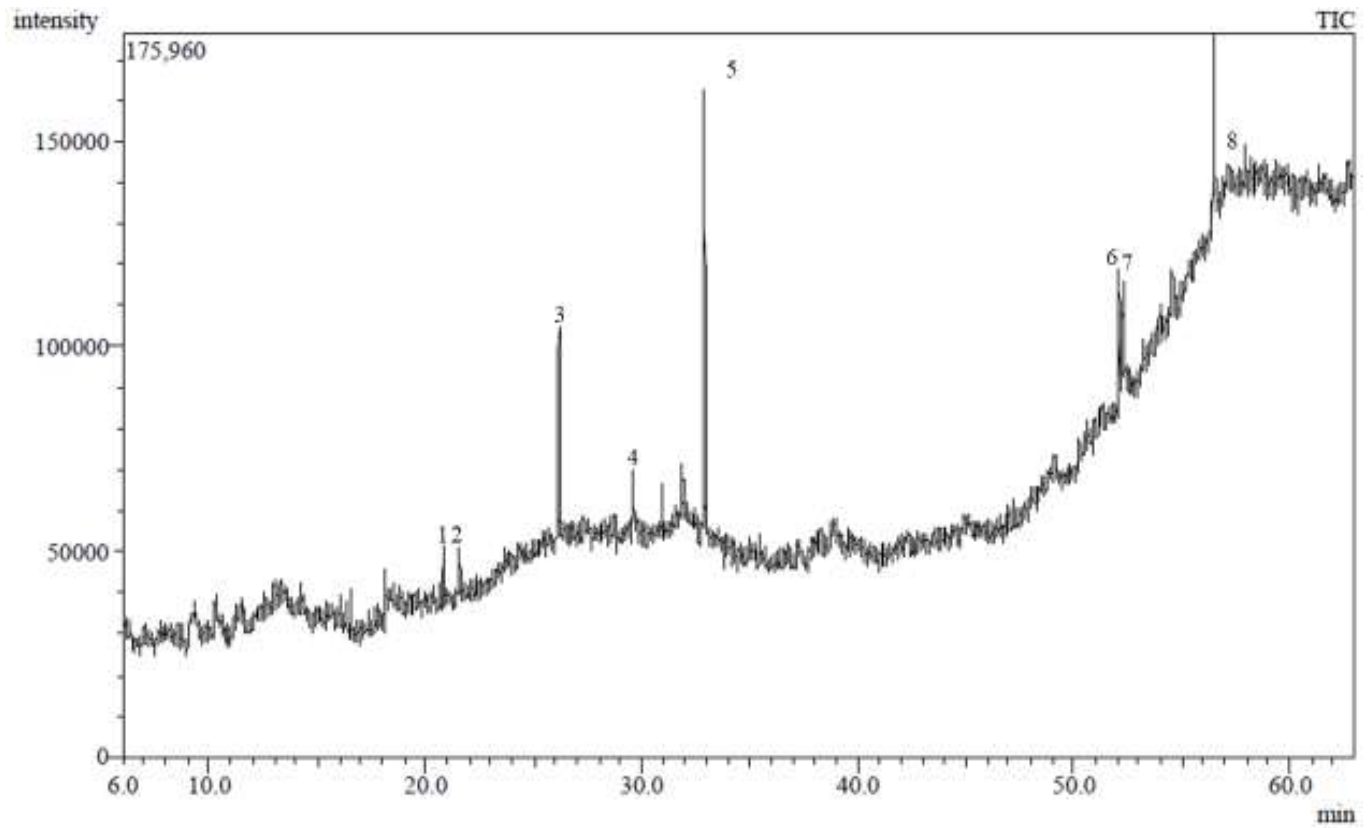

Fig. 7. Total ion chromatogram of GC-MS of $N$. arenaria hexane extract.

\section{CONCLUSION}

As $N$. arenaria hexane extract was effective in mycelium growth inhibition of Macrophomina phaseolina and Fusarium oxysporum, it would be considered a promising bio-agent source for biological control of diseases caused by those two fungi. This is considered ecofriendly method to the environment. 


\section{REFERENCES}

[1] Scala, S. and Bowler, C. "Molecular insights into the novel aspects of diatom biology," Cell. Mol. Life Sci. C., vol. 58, no. 11, pp. 1666-1673, 2001.

[2] Michalak, I. and Chojnacka, K. "Algae as production systems of bioactive compounds," Eng. Life Sci., vol. 15, no. 2, pp. 160-176, 2015.

[3] Ibraheem, B. M. I. Hamed, S. M. Abd Elrhman, A. A. Farag, M. F. and Abdel-Raouf, N. "Antimicrobial activities of some brown macroalgae against some soil borne plant pathogens and in vivo management of Solanum melongena root diseases," Aust J Basic Appl Sci, vol. 11, pp. 157-168, 2017.

[4] Soliman, A. S. Ahmed, A. Y. Abdel-Ghafour, S. E. El-Sheekh, M. M. and Sobhy, H. M. “Antifungal bio-efficacy of the red algae Gracilaria confervoides extracts against three pathogenic fungi of cucumber plant," Middle East J Appl Sci, vol. 8, pp. 727-735, 2018.

[5] Abdel-Kader, M. M. "Field application of Trichoderma harzianum as biocide for control bean root rot disease," Egypt. J. Phytopathol, vol. 25, no. 1-2, pp. 19-25, 1997.

[6] Hewedy, M. A. Rahhal, M. M. H. and Ismail, I. A. "Pathological studies on soybean damping-off disease,” Egypt J Appl Sci, vol. 15, pp. 88-102, 2000.

[7] Okunowo, W. O. "Antimicrobial, Antioxidant Potential and Chemical Composition of the Methanolic Extracts of Spirogyra setiformis and Navicula species," J. Sci. Res. Dev., vol. 17, no. 1, pp. 15-20, 2017.

[8] Qin, J. G. Trent, D.W. Zhang, and C. Franco, "Discovery of antimicrobial activities of a marine diatom Thalassiosira rotula," African J. Microbiol. Res., vol. 7, no. 50, pp. 5687-5696, 2013.

[9] Sherief, M. A. El-Bassyouni, G. T. Gamal, A. A. and Esawy, M. A. "Modification of diatom using silver nanoparticle to improve antimicrobial activity," Mater. Today Proc., vol. 43, no. 6, pp. 69-74, 2021.

[10] Guillard, R. R. L. "Culture of phytoplankton for feeding marine invertebrates," in Culture of marine invertebrate animals, Springer, 1975, pp. 29-60.

[11] Donkin, A. S. "On the marine Diatomaceae of Northumberland, with a description of eighteen new species," Trans. Microsc. Soc., vol. 5, pp. 12-34, 1858.

[12] Ausubel, F. M. Brent, R. Kingston, R.E. Moore, D.D. Seidman, J.G., Smith, J.A. Struhi, K.“Current Protocols in Molecular Biology (Janssen, K., ed) John Wiley \& Sons,” Inc., New York, 1994.

[13] White, T. J. Bruns, T. Lee, S. and Taylor, J. "Amplification and direct sequencing of fungal ribosomal RNA genes for phylogenetics," PCR Protoc. a Guid. to methods Appl., vol. 18, no. 1, pp. 315-322, 1990.

[14] Altschul, S. F. Madden, T.L. Schäffer, A.A. Zhang, J. Zhang, Z. Miller, W. and Lipman, D. J. "Gapped BLAST and PSI-BLAST: a new generation of protein database search programs," Nucleic Acids Res., vol. 25, no. 17, pp. 3389-3402, 1997.

[15] Tamura, K. Dudley, J. Nei, M. and Kumar, S. "MEGA4: molecular evolutionary genetics analysis (MEGA) software version 4.0," Mol. Biol. Evol., vol. 24, no. 8, pp. 1596-1599, 2007.

[16] Mundt, S. Bui, H.T. Preisitsch, M. Kreitlow, S. Bui, H.T. Pham, H.T. Zainuddin, E. Le, T.T. Lukowski, G. and Jülich, W.D. "Microalgae - a promising source of novel therapeutics," JSM Biotechnol Bioeng, vol. 2, no. 1, pp. 1-12, 2014.

[17] Abdel-Aal, E. I. Haroon, A. M. and Mofeed, J. "Successive solvent extraction and GC-MS analysis for the evaluation of the phytochemical constituents of the filamentous green alga Spirogyra longata," Egypt. J. Aquat. Res., vol. 41, no. 3, pp. 233-246, 2015.

[18] Lotfi, A. Kottb, M. Elsayed, A. and Shafik, H. “Antifungal activity of some Mediterranean seaweed 
against Macrophomina phaseolina and Fusarium oxysporum in Vitro," Alfarama J. Basic Appl. Sci., vol. 2, no. 1, pp. 81-96, 2021.

[19] Moubayed, N. M. S. Al Houri, H. J. Al Khulaifi, M. M. and Al Farraj, D. A. "Antimicrobial, antioxidant properties and chemical composition of seaweeds collected from Saudi Arabia (Red Sea and Arabian Gulf)," Saudi J. Biol. Sci., vol. 24, no. 1, pp. 162-169, 2017.

[20] Bhore, S. J. Ravichantar, N. and Loh, C. Y. "Screening of endophytic bacteria isolated from leaves of Sambung Nyawa [Gynura procumbens (Lour.) Merr.] for cytokinin-like compounds," Bioinformation, vol. 5, no. 5, p. 191, 2010.

[21] Bodet, C. A. Jorgensen, J. H. and Drutz, D. J. "Simplified bioassay method for measurement of flucytosine or ketoconazole.," J. Clin. Microbiol., vol. 22, no. 2, pp. 157-160, 1985.

[22] De Corato, U. Salimbeni, R. De Pretis, A. Avella, N. and Patruno, G. "Antifungal activity of crude extracts from brown and red seaweeds by a supercritical carbon dioxide technique against fruit postharvest fungal diseases," Postharvest Biol. Technol., vol. 131, pp. 16-30, 2017.

[23] Gomez, K. A. and Gomez, A. A. Statistical procedures for agricultural research. John Wiley \& Sons, 1984.

[24] Cox, E. J. "Studies on the diatom genus Navicula Bory. VII. The identity and typification of Navicula gregaria Donkin, N. cryptocephala Kütz. and related taxa," Diatom Res., vol. 10, no. 1, pp. 91-111, 1995.

[25] Seenivasan, R. Indu, H. Archana, G. and Geetha, S. "The antibacterial activity of some marine algae from south east coast of India.," J. Pharm. Res., vol. 3, no. 8, pp. 1907-1912, 2010.

[26] Celis, C. García, A. Sequeda, G. Mendez, G. and Torrenegra, R. "antimicrobial activity of extracts obtained from anacardium excelsumagaints some pathogenic microorganisms," Emirates J. Food Agric., pp. 249-257, 2011.

[27] Akhtar, R. Javaid, A. and Qureshi, M. Z. "Bioactive Constituents of Shoot Extracts of Sisymbrium irio L. Against Fusarium oxysporum f. sp. cepae," Planta Daninha, vol. 38, 2020.

[28] Ridho, M. R. Setiawan, A. and Patriono, E. "Bioactive Compounds Evaluation of the Mudskippers in the Estuarine Area of Musi River, South Sumatera, Indonesia," J. Ecol. Eng., vol. 21, no. 3, 2020.

[29] Gopinath, S. Sakthidevi, G. Muthukumaraswamya, S. and Mohan, V. R. "GC-MS analysis of bioactive constituents of Hypericum mysorense (Hypericaceae).," J. Curr. Chem. Pharm. Sci., vol. 3, no. 1, pp. 6-15, 2013.

[30] Rajesh, K. D. Vasantha, S. Panneerselvam, A. Rajesh, N. V. and Jeyathilakan, N. "Phytochemical analysis, in vitro antioxidant potential and gas chromatography mass spectrometry studies of Dicranopteris linearis," Asian J Pharm Clin Res, vol. 9, no. 2, pp. 1-6, 2016. 